\title{
Teaching tools in dental carving: models, virtual resources, and interactivity
}

\author{
Jussara Peixoto Ennes*; Albert Schiaveto Souza**; Inara Pereira da Cunha***; Rayssa Pereira

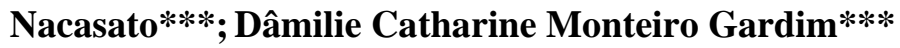

* Ph.D, Associate Professor of Human and Dental Anatomy, Biosciences Institute, Federal University of Mato Grosso do Sul

** Ph.D, Associate Professor and Director of the Biosciences Institute, Federal University of Mato Grosso do Sul

*** Former student, School of Dentistry, Federal University of Mato Grosso do Sul

Received July 13, 2017. Accept October 21, 2017.

\begin{abstract}
This study aimed to access students' perception evaluating the usefulness of the Three-Stages Sculpture Geometric Technique and auxiliary tools to learn dental anatomy and the impact of this on their grades. Wax models and resources in the virtual environment, such as demonstration videos of carving technique, classes' files, online tests, and forums were offered to two groups of students. Students' perception was collected using a questionnaire. A comparison between their grades and the virtual resources' frequency use was made; between the grades of the two groups and between theirs and those obtained by a third group, which did not use these tools. Students rated favorably the technique, the wax models, the videos and the other resources offered in a virtual environment. The models were considered more efficient as an aid to learning than were the videos, with a significant difference. There was no relation between the frequency to the videos and also to the other virtual resources offered, and the results in grades of the students of Group A and B. The mean grade of both Groups did not differ. There was a positive difference on final grade of Group B students who visited all the virtual resources offered compared with those that didn't. The applied carving technique provided and facilitated learning of dental anatomy and the aid given by the models was more efficient. Interactivity seemed expendable to improve results in grades.
\end{abstract}

Descriptors: Dental Education, Anatomy, Sculpture. 


\section{INTRODUCTION}

Teaching methodologies to dental anatomy vary $^{1-5}$. Carving has been advocated for developing cognitive and motor skills ${ }^{1,5}$. The choice of the method to teach dental anatomy is based on several reasons ${ }^{3,4}$, and it should consider the available budget, student/professor ratio, curriculum and desired professional profile. Due to the high student/teacher ratio, in the School of Dentistry of the Federal University of Mato Grosso do Sul (FAODO/UFMS) a geometric method using models was thought as being suitable. The Three-stages Sculpture Geometric Technique (TST) has been applied in an attempt to provide conditions under which the student can acquire dental anatomy knowledge when still in the second semester.

The development of virtual reality and the concomitant changing student profile suggest that activities that disseminate knowledge in a virtual environment can be attractive and potentially more efficient. It is considered that virtual environment offers flexibility regarding time and source; increases connectivity between teachers, students and among peers; and promotes improvement in grades $^{6}$. The efficacy of courses that integrate traditional teaching with the use of online resources has been widely debated ${ }^{4,6-8}$, despite increasing use. In this model of learning, interactivity is said to be mandatory. Distance Learning (DL) at UFMS uses the web environment Moodle $\mathrm{e}^{9,10}$. The availability of this virtual environment at UFMS prompted the production and supply of TST demonstration videos and other resources as aids to classroom teaching. Moreover, also low-cost educational tools that allow students to develop independently are highly desirable. The investigation on student's acceptance to these tools and to their impact on the learning process is required.

This study aimed to identify how students evaluated the TST as a method to learn dental anatomy, and also the help of different tools as models, videos and virtual resources in the learning process and, finally, to investigate if the use of these tools reflects in their results in grades.

\section{METHODS}

The project was approved by the Research Ethics Committee of UFMS under protocol number 1916 and CAAE 0111.0.049.000-11. Students that agreed to participate in the study signed an informed consent form.

A total of 31 students was included. The presentation and use of the TST took place during dental anatomy course taught in four-hour-long weekly classes over 17 weeks, when the students were allocated into two groups. Prior to the beginning of each class, students were required to submit a summarized written anatomical description of the tooth based on the indicated literature $^{11}$. At the beginning of each class, the detailed anatomy of each tooth was taught and the carving technique was demonstrated in person. For the illustration of the TST in this text, the description of its execution is presented using the permanent maxillary central incisor.

In the Geometric Phase (figure 1A), a cuneiform shape is given to the warm wax stick (\#34890 - Kerr Corporation, Orange, USA) tip, using the fingers (figure 2A). Then, with the help of a LeCron carver (Surtex Instruments Ltd., Birmingham, UK), the surfaces of the future crown are obtained with the geometric form, which they are related to and also inclined, applying the rules of dental surface directions ${ }^{11}$. The root segment is carved with a cylindrical form. Central incisor measurements ${ }^{12}$ are applied with 
the help of a bow compass and a millimeter ruler. In the Carving of the Crown Initial Phase (figure 1B), its anatomical features are carved with the help a Hollenback \#3 carver (S.S. White Duflex, Juiz de Fora, Brazil) and a \#7 wax spatula (Metalúrgica Fava Indústria e Comércio Ltda, São Paulo, Brazil) (figure 3). In the Root Carving, Crown Finalization and Finishing Phase (figure 1C), a solid conic form is given to the root, but with a slight inclination of its proximal surfaces to the palatal side. The cervical line must be obtained between root and crown, and the details of crown's anatomical features are refined.

Sets of three wax TST models of each tooth to be carved (figures 1A, B and C) were produced with senior students' help in an amount that each set could be shared by up to three students during all classes. A real tooth was also included to a set of models that remained on the front bench to be consulted by all students. The demonstration of the TST execution of each tooth was filmed using a Sony Cyber-shot DSC-HX1 Digital Camera mounted on a STC-360 Lightweight Tripod and offered in the Moodle environment, hosted on the UFMS DL site. It was suggested that the videos should be used to carve the homologous tooth, as homework. No interaction occurred between these students and the teacher through the Moodle environment. Moodle generated information regarding the frequency of video access.

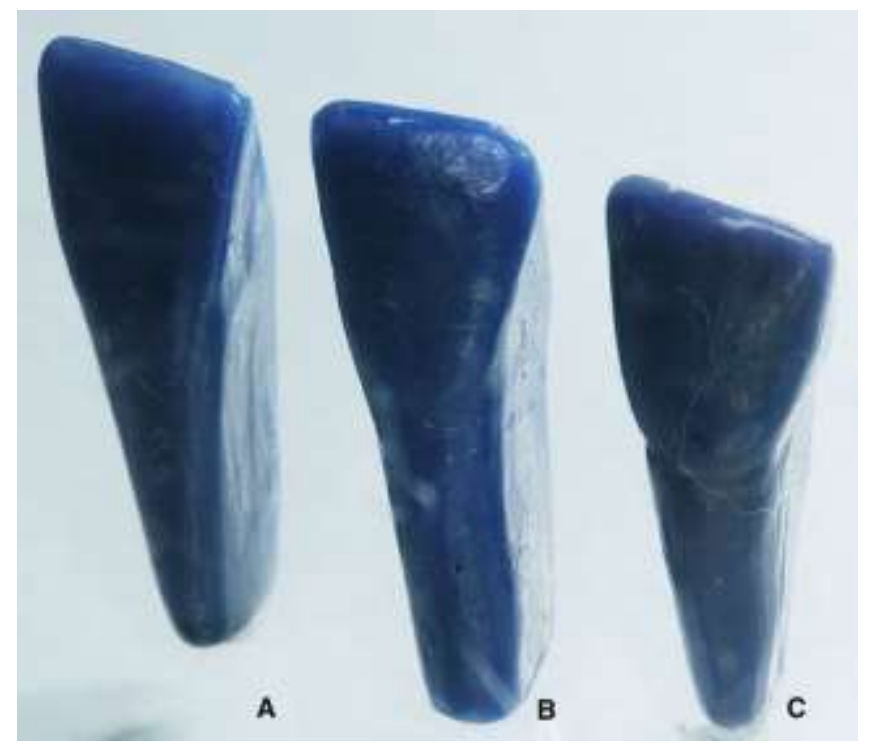

Figure 1. Models of the three carving phases of the permanent maxillary central incisor obtained by using TST. A: geometric phase; B: initial crown sculpture phase; C: phase of root carving, crown finalization and finishing. 


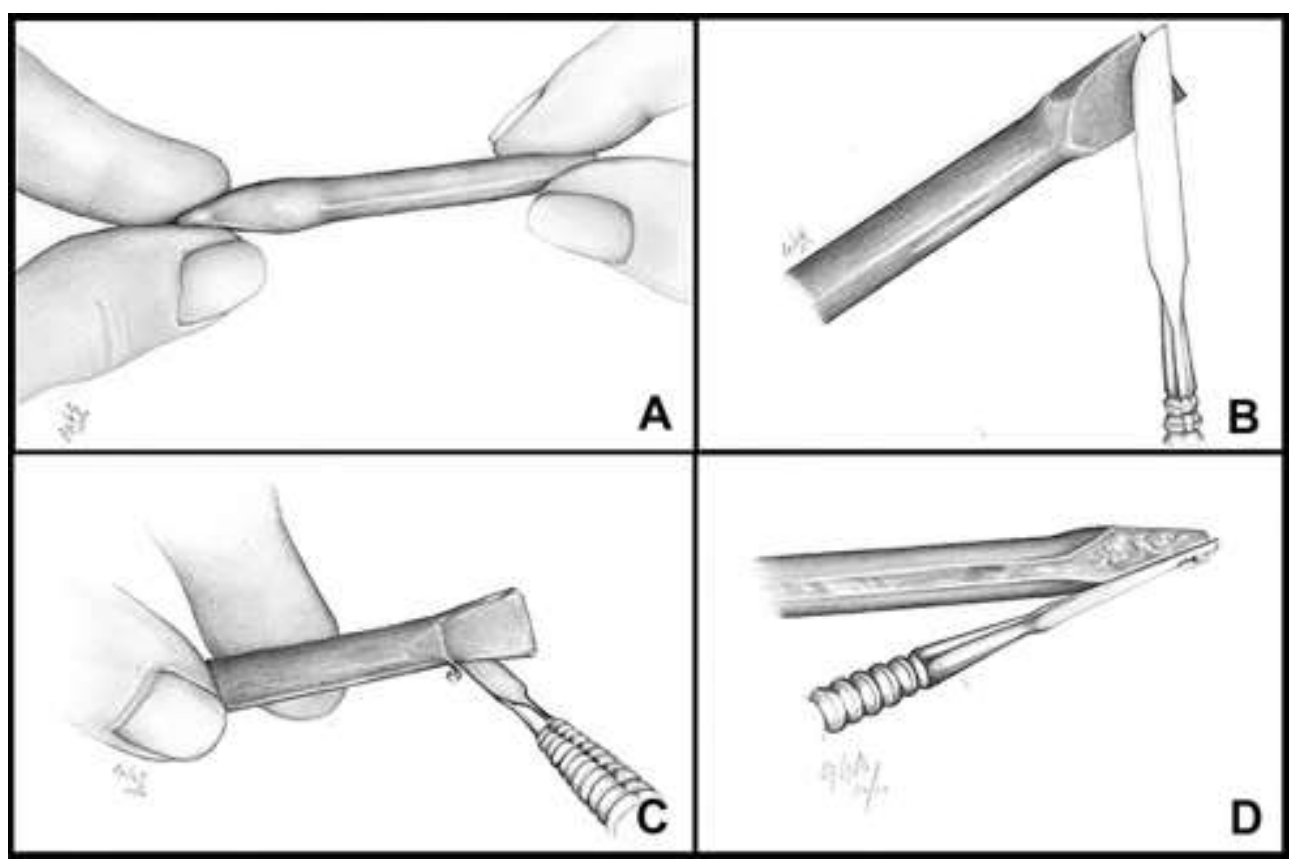

Figure 2. Obtaining the geometric shape of the crown of the permanent maxillary central incisor. A- Finger modeling of a wedge shape; B- obtaining the smoothing on the surfaces of the crown and straight edges, within the limits between the surfaces; C- obtaining the trapezoidal shape on the buccal surface; D- tilt of the lingual surface toward the incisal edge.

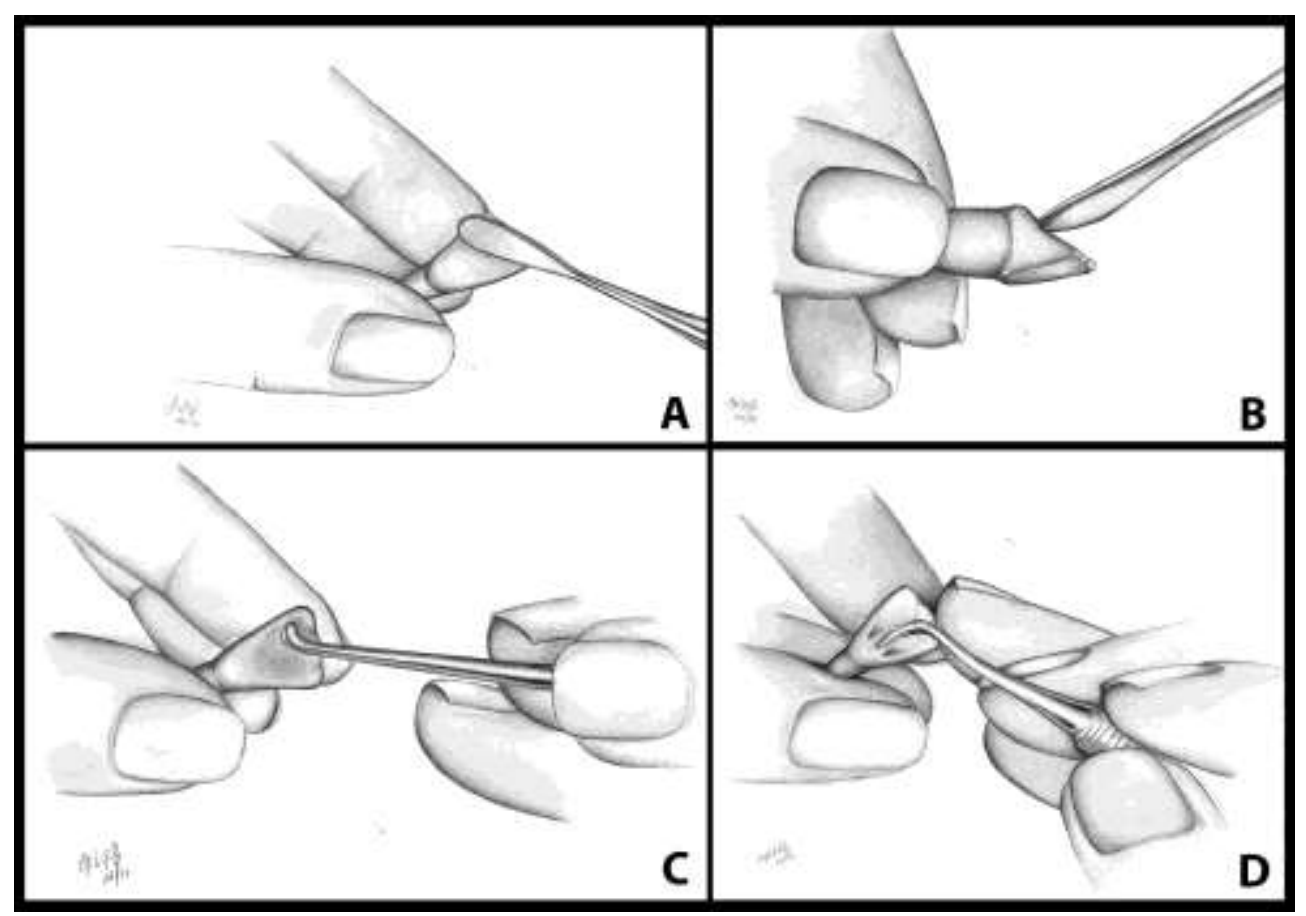

Figure 3. Carving of anatomical features on the lingual surface. A- lingual fossa. B- profile of the marginal ridge, observed from the proximal surfaces. C- marginal ridges. D- cingulum projections. 
The total number of views for each student was transcribed for analysis. Two subgroups were established considering students' number of accesses to the videos in Moodle ambience, up to the day of each evaluation, resulting in a group of students with seven or more accesses and a group with up to six accesses or less.

A nine questions quiz designed to investigate the applicability and acquisition of knowledge using the TST and the other resources was provided to be anonymously answered by students. Four questions were multiple choices, and the rest were formatted for a scale response in which the participant assigned scores from 0 (poor) to 10 (excellent).

During the course, the carving of each tooth was evaluated at the end of the class when the student was individually instructed according to his work. The goals were: geometric form of dental surfaces, application of dental surfaces direction rules $^{11}$, compliance with dental measurements and accuracy of anatomical features sculpture. Once finished carving the anterior teeth set and then the posterior teeth set, these two groups of teeth were reevaluated, taking the class partial individual evaluations into account. Absences in practical lessons turned into subtraction of evaluation value of this tooth and its homolog of the total score. This requirement was added to prevent the students from turning in a non-identified/nonevaluated work when the set of carved teeth was submitted.

Students of Group B used TST in the same way as did Group A. The auxiliary tools offered to the Group A were also offered here. Additionally, the following resources were offered in the virtual environment: lesson scripts that consisted of PowerPoint-type presentations in PDF format of the lesson theoretical contents; discussion forums for topics related to the course syllabus and multiple choices tests on the theoretical content. The results of these tests were used as a grade incentive. A total of 38 students were included in Group B.

The evaluation of the wax models' use and videos and the relation between video visits and the grades obtained was performed in the same way as for Group A. A quiz with the same questions applied to Group A and including evaluation questions about the new resources offered and used was applied in the same way as in the previous class. The analyses that both cohorts performed according to the contribution of the wax models and videos to carving using the TST were analyzed together and comparatively.

Group C was comprised of 35 students who had no access to any resources in Moodle. One set of wax models of each tooth and a real one were available to the students in the front bench and they had free access for observation, during all classes. The grade means of this group were compared to those of Group A and Group B.

The evaluation of the linear correlation between the number of accesses to the videos or to the videos and other Moodle resources with the partial grades or final grades between Group A and $B$ was performed using the Pearson linear correlation test. The comparisons between Groups $\mathrm{C}$ and $\mathrm{A} ; \mathrm{C}$ and $\mathrm{B}$; and $\mathrm{A}$ and $\mathrm{B}$ regarding the mean grades were performed using Student's t test. The results of the variables evaluated in this study were presented as descriptive statistics or as tables. Statistical analysis was performed using the SigmaPlot version 12.5 software, considering a significance level of $5 \%$.

\section{RESULTS}

Table 1 shows the results related to the evaluation performed by Group A and B students 
regarding the use of the technique, wax models and videos and other virtual resources.

Table 2 shows the results of the questions answered by the students using scores of zero to ten to evaluate the same items. Regarding Group A results, there was no significant linear correlation between the number of accesses to the videos on Moodle relative to the first evaluation and to the grade of the students (Pearson, $\mathrm{p}=$ $0.662, r=0.082)$, neither to the second evaluation $(\mathrm{p}=0.089, \mathrm{r}=0.310)$ nor to the final grade $(\mathrm{p}=$
$0.333, \mathrm{r}=0.180)$.

The mean grade of the students who visited Moodle up to six times or less was $6.84 \pm 1.61$, while those who made seven or more visits had a mean grade of $5.91 \pm 1.5$. There was no difference in grades between students who visited more and those who visited less (Student's $t, p=0.127$ ). The difference in the mean grade of Group $C$, who did not have access to videos on Moodle $(6.93 \pm 1.57)$, and Group A $(6.84 \pm 1.61)$ was not statistically significant (Student's t, $\mathrm{p}=0.068$ ).

Table 1. Numerical and percentage distribution of students according to answers on the questionnaire evaluating the TST, the use of models, video of the technique demonstration and other resources offered in a virtual environment. $\mathrm{n}$ : number of students

$\%(\mathbf{n})$

\section{Questions}

Group A Group B

\begin{tabular}{|c|c|c|c|}
\hline \multirow[t]{2}{*}{ Does the technique presented allow the carving of permanent teeth? } & No & $3.2(1)$ & $2.6(1)$ \\
\hline & Yes & $96.8(30)$ & $97.4(37)$ \\
\hline Does the technique facilitate understanding of the anatomy of & No & $3.2(1)$ & $0(0)$ \\
\hline permanent teeth? & Yes & $96.8(30)$ & $100(38)$ \\
\hline Do the wax models used in the practical lessons help you understand & No & $3.2(1)$ & $0(0)$ \\
\hline the phases of the technique? & Yes & $96.8(30)$ & $100(38)$ \\
\hline Do the videos available for consultation in the virtual environment & No & $6.5(2)$ & $18.4(7)$ \\
\hline (Moodle, DL/UFMS) help you to understand the technique? & Yes & $93.5(29)$ & $81.6(38)$ \\
\hline Do the lesson scripts offered in the virtual environment facilitate the & No & & $2.6(1)$ \\
\hline understanding of dental anatomy? & Yes & & $97.4(37)$ \\
\hline Do the discussion forums in the virtual environment stimulate your & No & & $47.4(18)$ \\
\hline search for dental anatomy knowledge? & Yes & & $52.6(20)$ \\
\hline Do the tests available in the virtual environment contribute to your & No & & $21.0(8)$ \\
\hline learning of dental anatomy? & Yes & & $19.0(31)$ \\
\hline
\end{tabular}


Group B results showed no significant linear correlation between the number of visits to the Moodle environment in the first evaluation period and the grade (Pearson, $\mathrm{p}=0.464, \mathrm{r}=0.122$ ), neither to the second evaluation period $(\mathrm{p}=0.489$, $r=0.116)$ nor the final grade $(p=0.229, r=0.200)$.

There was no difference regarding mean grades between participants who visited less $(6.72$ $\pm 1.73)$ and those who visited more $(6.82 \pm 1.79)$ $(\mathrm{p}=0.869)$. When the final grade was compared to access to all the resources offered in Moodle (videos, scripts, forums and tests), there was a significant difference (Pearson, $\mathrm{p}=0.004, \mathrm{r}=$ 0.455). A slightly positive difference was identified between the mean grade of the students of Group C, who did not access the videos on Moodle $(6.93 \pm 1.57)$ and that of the Group B students $(6.76 \pm 1.73)$ (Student's $t, p=0.656)$. There was no difference between students of Group A (6.21 \pm 1.57$)$ and those of Group B (6.76 \pm 1.73 ) who used more the virtual resources in the Moodle environment ( $\mathrm{p}=0.178)$.

Table 2. Assignment of values to questions evaluating the TST, the use of models and video demonstrations of the technique and other resources offered in a virtual environment.

\begin{tabular}{|c|c|c|c|c|c|c|c|c|c|c|}
\hline \multirow[t]{2}{*}{ Questions } & \multicolumn{2}{|c|}{$\begin{array}{c}\text { n } \\
\text { Group }\end{array}$} & \multicolumn{2}{|c|}{$\begin{array}{c}\text { M } \\
\text { Group }\end{array}$} & \multicolumn{2}{|c|}{$\begin{array}{c}\text { RV } \\
\text { Group }\end{array}$} & \multicolumn{2}{|c|}{$\begin{array}{c}\text { Min } \\
\text { Group }\end{array}$} & \multicolumn{2}{|c|}{$\begin{array}{c}\text { Max } \\
\text { Group }\end{array}$} \\
\hline & $\mathbf{A}$ & B & $\mathbf{A}$ & B & $\mathbf{A}$ & B & $\mathbf{A}$ & B & $\mathbf{A}$ & B \\
\hline $\begin{array}{l}\text { On a scale of } 0 \text { (poor) to } 10 \text { (excellent), how do you rate } \\
\text { the effectiveness of the three-stages geometric technique? }\end{array}$ & 31 & 38 & 10 & 10 & 2 & 0 & 8 & 0 & 10 & 10 \\
\hline $\begin{array}{l}\text { On a scale of } 0 \text { (poor) to } 10 \text { (excellent), how do you rate } \\
\text { the practicality of the three-stages geometric technique? }\end{array}$ & 31 & 38 & 9 & 9 & 3 & 4 & 7 & 6 & 10 & 10 \\
\hline $\begin{array}{l}\text { On a scale of } 0 \text { (poor) to } 10 \text { (excellent), how do you rate } \\
\text { the contribution of the wax models used in the practical }\end{array}$ & 31 & 38 & 10 & 10 & 3 & 4 & 7 & 6 & 10 & 10 \\
\hline $\begin{array}{l}\text { On a scale of } 0 \text { (poor) to } 10 \text { (excellent), how do you rate } \\
\text { the contribution of the videos available in the virtual }\end{array}$ & 31 & 38 & 9 & 8 & 8 & 5 & 2 & 5 & 10 & 10 \\
\hline $\begin{array}{l}\text { On a scale of } 0 \text { (poor) to } 10 \text { (excellent), how do you rate } \\
\text { the acquisition of knowledge regarding dental anatomy }\end{array}$ & 31 & 38 & 9 & 9 & 4 & 6 & 6 & 4 & 10 & 10 \\
\hline $\begin{array}{l}\text { On a scale of } 0 \text { (poor) to } 10 \text { (excellent), how do you rate } \\
\text { the importance of the lesson scripts for understanding the }\end{array}$ & & 38 & & 10 & & 10 & & 0 & & 10 \\
\hline $\begin{array}{l}\text { On a scale of } 0 \text { (poor) to } 10 \text { (excellent), how do you rate } \\
\text { the interactivity provided by the forums for your learning? }\end{array}$ & & 38 & & 7 & & 8 & & 2 & & 10 \\
\hline $\begin{array}{l}\text { On a scale of } 0 \text { (poor) to } 10 \text { (excellent), how do you rate } \\
\text { the contribution of tests in the virtual environment to your }\end{array}$ & & 38 & & 8 & & 6 & & 4 & & 10 \\
\hline
\end{tabular}

n: number of students; M: median; RV: range of variation; Min: minimum; Max: maximun 
When the responses of the two cohorts regarding to the evaluation on a scale of 0 (poor) to 10 (excellent) points concerning the contribution of wax models in TST were analyzed together, the scores ranged between six and ten points, with a median score of ten points $(25 \%$ quartile $=9 ; 75 \%$ quartile $=10$ ). Furthermore, regarding the evaluation of the videos' contribution, the score ranged from two to ten points, with a median score of eight points $(25 \%$ quartile $=7,75 \%$ quartile $=10$ ). When compared to each other, the evaluation score of the wax models' contribution was significantly higher than that of the videos (Wilcoxon test, $\mathrm{p}<0.001$ ).

\section{DISCUSSION}

Carving is a desirable method for learning dental anatomy. This evidence is supported by neurophysiological studies ${ }^{14,15}$ and corroborated by both faculty ${ }^{3,5}$ and by students themselves ${ }^{1}$. It is also a non-expensive one. Geometric techniques might have some differences, but they have a common sequence of development.

The TST is a progressive technique for carving the crown and tooth root at a real size, which not only develops the motor and cognitive skills but also leads the student to produce his own collection of tooth models for present and future consultation and critical analysis. It was suitable to be applied in an institution with high student/professor ratio where investment in materials, equipment or virtual technology for teaching is limited. The implement of models seemed helpful to give students some independence to develop the technique. This also impelled introducing the videos as tools to stimulate independent progress in carving, which also took into consideration the change in student profile resulting from interaction with new technologies ${ }^{16}$. Since the TST was adopted at FAODO/UFMS, these advantages have been perceived but not quantified. The present study found that most students in both cohorts felt that the technique facilitates the carving of permanent human teeth and the understanding of its anatomy and agree that the wax models and technique demonstration videos aid in understanding the stages of the technique. The wax models had higher approval than the videos. The facilitative nature of the use of models in teaching dental anatomy has already been noted previously ${ }^{17}$.

The use of distance learning platforms has excellent potential as an aid to classroom teaching ${ }^{6,8}$. The use of complementary virtual resources in teaching has generated diverse results ${ }^{8,18,19}$. In the present study, although the vast majority of the students expressed a favorable opinion regarding the assistance provided by the videos in Moodle, visits were not regular and could not be related to good performance, as reflected in grades, in either cohort. This observation may indicate that some students have sufficient cognitive and motor skills to execute the TST with the aid of classroom demonstration and models, waiving the use videos. Other students may have limited cognitive and motor skills and do not improve significantly despite the aid of the resources, although they might feel and actually be helped by them. Also interesting to notice is that Group C had better results in grades than Group B, although the difference was small. This might suggest that the efforts to reach the goal of producing dental sculpture with less help reflected positively in the learning process, considering grades aspect. This result demands further investigation.

The interaction between peers and teachers has produced diverse results: it has been described 
as an important motivational factor ${ }^{16}$, related to performance in grades $^{8}$, considered not sufficient ${ }^{18}$ or seen as dispensable 5 . In the present study, students who used interactive resources obtained better grades than those in the same class (Group B) who did not use them, although the difference was weak, particularly when one considers that there was a grade incentive. The final grade of these students was no better than that of those who did not have access to these interactive features (Group A), as previously observed ${ }^{19,20}$. The students themselves, in the present study, did not give a high score to the interactive resources available in the evaluation. They consisted of forums where clinical cases chosen to apply the module subject were discussed. When interacting students seemed attached to present a proper answer more than discussing the issue. That could be related to insufficient knowledge to discuss the issue or the lack of inquisitive abilities, as the experience was new to all of them, who had never undertaken to learn interactive activities online before. These results are surprising and raise doubt regarding the importance of interactivity and indicate that other factors may be related to student achievement, such as personal interest, intrinsic motivation for acquiring knowledge $e^{7,19}$, preexisting skills, such as in the use of the computer, and also the ease of navigation of the virtual environment used ${ }^{21}$. These factors may be more relevant than the teaching methodology ${ }^{21}$. They also raise the need of further investigation to verify if different interacting activities would be more suitable or if non-virtual clinical cases discussions would be preferable.

Regarding to grade incentives, ethical commitment is an important issue because it has already been identified that students with good results in online quizzes ${ }^{22}$ and tests ${ }^{23}$ obtained unsatisfactory results in final examinations. In the present study, there was a grade incentive to students of Group B and a better result in the final grade could be related to it, although it was weak. This is a point that requires reevaluation for the development of this activity for classes to come.

Students did not analyze quantitative evaluation methodology of learning, applied in this study. Although they did not spontaneously proffer complains or discomfort with it, investigation of this aspect is also an interest for further investigation objecting improvement on the whole process of learning.

Considered as a limitation of this study, the Moodle platform did not offer the amount of time students remained using the videos and other resources, but only the number of accesses. This information could have been important to make other assumptions, as the relation of their persistence with the results in grades.

\section{CONCLUSION}

The TST technique was considerable suitable for the learning process of dental anatomy. The use of models of the technique stages was considered more efficient for the understanding and execution of the TST than the demonstration videos. The use of videos in a virtual environment aroused interest and was appreciated, but it was not related to the grades obtained. Regarding the use of other resources in the virtual environment, the relation with grades was relative, suggesting that better results in grades are subject to other factors such as intrinsic motivation, grade incentives and, finally, that interactivity was expendable to this goal. These teaching tools are all of the interest of the students, allow individual access and progress on the learning process, can be reused and updated, if necessary; and finally, do not demand high 
financial investments.

\section{ACKNOWLEDGEMENTS}

The authors thank Josué da Silva Coutinho and João Batista Souza for their valuable contributions in reviewing the description of the TST, in this text.

\section{RESUMO}

Ferramentas de ensino na escultura dentária: modelos, recursos virtuais e interatividade

O objetivo desse estudo foi o de verificar a percepção do aluno quanto à utilidade da Técnica Geométrica de Escultura em Três Fases e de alguns recursos auxiliares para aprender anatomia dentária e o impacto desse uso no resultado em notas. Modelos de cera e recursos no ambiente virtual, como vídeos de demonstração da técnica de escultura, arquivos das aulas, testes online e fóruns foram oferecidos a dois grupos de estudantes. A opinião dos alunos foi coletada usando um questionário. Foi realizada a comparação entre as notas obtidas e a frequência do uso dos recursos virtuais; entre as notas dos dois grupos e entre essas e as obtidas por um terceiro grupo, que não teve acesso a nenhuma dessas ferramentas. Os alunos avaliaram positivamente a técnica, os modelos, os vídeos e os demais recursos oferecidos no ambiente virtual. Os modelos foram considerados mais eficientes no auxílio ao aprendizado, com uma diferença significante. Não houve diferença entre a frequência aos vídeos e aos demais recursos virtuais oferecidos e o resultado em notas obtidas pelos estudantes dos Grupos A e B. Não houve diferença entre as médias entre os dois grupos. Houve uma discreta diferença positiva entre a nota final dos estudantes do Grupo B que visitaram todos os recursos virtuais oferecidos quando comparada aos demais, que não o fizeram. A técnica de escultura utilizada proporcionou e facilitou o aprendizado da anatomia dental e a ajuda oferecida pelos modelos foi considerada mais eficiente. A interatividade pareceu dispensável para o alcance desse objetivo.

Descritores: Educação em Odontologia, Anatomia, Escultura.

\section{REFERENCES}

1. Abu ER, Ewan K, Foley J, Oweys Y, Jayasinghe J. Self-directed study and carving tooth models for learning tooth morphology: Perceptions of students at the University of Aberdeen, Scotland. J Dent Educ. 2013; 77(9):1147-53.

2. Buchaim RL, Andreo JC, Rodrigues AC, Gonçalves JBO, Daré LR, Rosa Junior GM, et al. Multidisciplinary approach in the teaching of dental sculpture and anatomy. Int J Morph. 2014; 32(2):399-403.

3. Kilistoff AJ, Mackenzie L, D'Eon M, Trinder K. Efficacy of a step-by-step carving technique for dental students. J Dent Educ. 2013; 77(1):63-7.

4. Mitov G, Dillschneider T, Abed MR, Hohemberg G, Pospiech P. Introducing and evaluating MorphoDent, a Web-based learning program in dental morphology. J Dent Educ. 2010; 74(10):1133-9.

5. Obrez A, Briggs C, Buckman J, Goldstein L, Lamb C, Knight WG. Teaching clinically relevant dental anatomy in the dental curriculum: description and assessment of an innovative module. J Dent Educ. 2011; 75 (6):797-804.

6. Aspden L, Helm P. Making the connection in a blended learning environment. EMT 2004;41(3):245-252.

7. Delialioglu O. 2007. Investigation of source of motivation in a hybrid course. [Acesso em 8 mai. 2016]. Disponível em: http://www. eric.ed.gov/ERICDocs/data/ericdocs2sq1/cont 
ent_storage_01/0000019b/80/1b/a7/1b.pdf

8. Seluakumaran K, Jusof FF, Ismail R, Husain R. Integrating an open-source course management system (Moodle) into the teaching of a first-year medical physiology course: a case study. Adv Physiol Educ. 2011; 35(4):369-77.

9. Dougiamas M, Taylor PC. 2003. Moodle: using learning communities to create an Opens Source Management System. [Acesso em 23 out. 2015]. Disponível em: https:// dougiamas.com/archives/edmedia2003/

10. Moodle. 2014. Moodle organization. [Acesso em 30 abr. 2015]. Disponível em: www.moodle.org

11. Picosse M. Anatomia Dentária. $4^{\text {th }}$ Ed. São Paulo: Sarvier, 1983.

12. Nelson SJ, Ash MM. Wheeller's Dental Anatomy, Physiology and Occlusion. $9^{\text {th }} \mathrm{ed}$. St Louis: Saunders Elsevier; 2010.

13. Shott S. Statistics for health professional. London: W. B. Saunders Company, 1990.

14. Conway J. Educational technology's effects on models of instructions. [Acesso em 5 abr. 2015]. Disponível em: http://www.irfaner dogan.com/egitim/Educational\%20Technol ogy.htm

15. Horst J, Clark MD, Lee AH. Observation, assisting, apprenticeship: cycles of visual and kinesthetic learning in dental education. J Dent Educ. 2009; 73(8):919-33.

16. Lange $\mathrm{P}$, Suwardy $\mathrm{T}$, Mavondo $\mathrm{F}$. Integrating a virtual learning environment into an introductory accounting course: determinants of students' motivation. Accounting Education. 2003; 12(1):1-14.

17. Cantín M, Muñoz M, Olate S. Generation of 3D tooth models based on three-dimensional scanning to study the morphology of permanent teeth. Int J Morphol. 2015; 33(2): 782-7.

18. Gossnhelmer AN, Ben T, carneiro MLF, Castro M. Impact of distance education on academic performance in pharmaceutical care course. PLoS One. 2017; 12(4):1-11.

19. Dantas AM, Kemm RE. A blended approach to active learning in a physiology laboratorybased subject facilitated by an e-learning component. Adv Physiol Educ. 2008; 32(1): 65-75.

20. Al-Thobity AM, Farooq I, Khan SQ. Effect of software facilitated teaching on final grades of dental students in a dental morphology course. Saudi Med J. 2017; 38(2):192-5.

21. Wright EF, Hendricson WD. Evaluation of a 3-D interactive tooth atlas by dental students in Dental Anatomy and Endodontics courses. J Dent Educ. 2010; 74(2):110-22.

22. Dobson JL. The use of formative online quizzes to enhance class preparation and scores on summative exams. Adv Physiol Educ. 2008; 32(4): 297-302.

23. Kibble J. Use of unsupervised online quizzes as formative assessment in a medical physiology course: effects of incentives on student participation and performance. Adv Physiol Educ. 2007; 31(3):253-60.

Correspondence to:

Jussara Peixoto Ennes

e-mail: jussarapeixotoennes@gmail.com

Instituto de Biociências, UFMS

Av. Costa e Silva, s/n - Cidade Universitária

79070-900 - Campo Grande/MS - Brasil 